\title{
Survival rights for children: What are the national and global barriers?
}

\author{
Bernadette Ann-Marie O'Hare* \\ Senior lecturer in Global Health Implementation and in Paediatrics and Child \\ Health, School of Public Health, College of Medicine, Malawi and University of \\ St Andrews, United Kingdom
}

Eva Maria Mfutso Bengo**

Lecturer in Law, University of Malawi

Delan Devakumar***

Clinical Associate Professor in Child and Adolescent Health, Institute for Global Health, University College London

Joseph Mfutso Bengo****

Professor of Bioethics and Director of Centre for Bioethics, School of Public Health, College of Medicine, Malawi

\section{Summary}

Most children die in low and middle-income countries as a result of structural injustice, and while it may not be possible to prove causality between economic policies and breaches of rights, it is possible to audit policy and practices through the lens of human rights. Child health advocates need to highlight the fact that technical interventions, in the absence of action on structural injustice, cannot address the fundamental causes of poor health. It could even be said that we collude in the fallacy that injustices can be solved with technical solutions. The determinants of health, water, food, shelter, primary education and health care are minimum core human rights, are the rights required for survival and today should be available to every child (and their families) in all countries. However, there are national and global limitations on the ability of countries to determine policy and generate the revenue required for core

\footnotetext{
* MD MPH FRCPCH DTM\&H MB BCh BAO; bamo@st-andrews.ac.uk

** Volljurist; ebengo@poly.ac.mw

*** MB ChB MRCPCH FFPH MSc DTM\&H PhD; d.devakumar@ucl.ac.uk

**** MAPhD; mfutsobengo@medcol.mw
} 
human rights. The authors conducted a review of the literature on the main leakages from government revenues in low and middle-income countries to identify obstacles to children enjoying their right to survival. Based on the review the authors suggest a framework for an upstream audit that can be carried out, country by country, to identify barriers in terms of policies and the generation, allocation and utilisation of revenues. This audit involves systematically screening the policies and practices of the main actors: national governments, high-income country partners, multinational enterprises, and international organisations, for possible influence on the realisation of human rights. Human rights advocates and child health associations could lead or commission an upstream audit on behalf of children in their countries in order to identify the fundamental causes and real remedies.

Key words: minimum core economic and social rights; human rights impact assessment; economic policies; duty bearers; low and middleincome countries; socio-economic rights; survival rights; children's rights

\section{Introduction}

It is known that in order to survive and be healthy children require clean water, sanitation, health care and education. ${ }^{1}$ These are the minimum core economic and social rights that are critically important for children. If children do not enjoy these rights and if their mother is uneducated, they are less likely to survive. Since they are required for survival, these rights could (or should) be called survival rights. ${ }^{2}$ Most children in high-income countries have access to these rights, but many children in low and middle-income countries do not, which results in different outcomes, see box 1 and figure1. The risk of a child dying before the age of five years in low-income countries is 14 times higher than in high-income countries, namely, 69 per 1000 live births in comparison with five per 1000 live births. ${ }^{3}$ The fundamental causes of preventable child mortality are limited access to the determinants of health or survival rights, and healthcare interventions can only mitigate the impact. ${ }^{4}$

The UN Committee on Economic, Social and Cultural Rights (ESCR Committee) stated that these rights are of immediate effect and serve as the lowest bar for countries to progressively realise other human

1 S Kuruvilla, J Schweitzer, D Bishai et al 'Success factors for reducing maternal and child mortality' (2014) 92 Bulletin of the World Health Organisation 533.

2 S Pemberton, D Gordon, S Nandy et al 'Child rights and child poverty: Can the international framework of children's rights be used to improve child survival rates?' (2007) 4 PLoS Medicine 1567.

3 World Health Organizaton 'Global Health Observatory Data' (2017) http:// www.who.int/gho/en/ (accessed 18 November 2018).

4 B O'Hare, D Devakumar \& S Allen 'Using international human rights law to improve child health in low-income countries?: A framework for healthcare professionals' (2016) 16 BMC International Health and Human Rights 11. 
rights. ${ }^{5}$ Many governments of low and middle-income countries do not have adequate revenue to provide the public services that are essential to ensure core rights. However, international human rights law tends to identify the nation state as the sole duty bearer of core economic and social rights, despite the reduced policy space available in a globalised world. $^{6}$ Yet, all states have extra-territorial responsibilities regarding human rights and, similarly, countries that have delegated powers to international organisations are responsible for the decisions of those bodies. ${ }^{7}$ In addition, General Comment 24 of the ESCR Committee states that high-income countries should not remain passive but must act to prevent violations of survival rights abroad by entities domiciled in their territories. ${ }^{8}$ At the same time, reduced room for manoeuvre does not exonerate low and middleincome countries from their responsibilities, and they also are responsible for the conduct of entities that operate in their territory or that undertake state functions. ${ }^{9}$

This interdisciplinary article aims to propose a four-step framework to facilitate an audit of the national and international influences on survival rights. It is suggested that this audit is carried out one country at a time, as the influences vary from country to country. The purpose of the audit is to identify barriers in order to propose remedies.

\section{Methods: Developing a tool to audit the upstream influences on survival rights}

For most children, access to survival rights depends on public services (water, sanitation, health care and education), that generally are provided by governments. Government revenue, as well as allocation decisions, will influence the amount that is available for public services and thus survival rights. Government revenue in low and middleincome countries derives from tax (70 per cent), non-tax revenues and user fees (11 per cent) and grants or aid (17 per cent). ${ }^{10}$

Governments determine domestic taxation policies, but there are significant and interwoven global influences on taxation, and low and

5 ESCR Committee UN E/C.12/2000/4 General Comment 14 (2000): The right to the highest attainable standard of health (art 12) para 43.

6 E Ashford 'The infliction of subsistence deprivations as a perfect crime' (2018) 118 Proceedings of the Aristotelian Society 83.

7 Maastricht Principles on Extraterritorial Obligations of States in the Area of Economic, Social and Cultural Rights (2011).

8 ESCR Committee E/C.12/GC/24 General Comment 24 on State Obligations under the International Covenant on Economic, Social and Cultural Rights in the Context of Business Activities (2017) para 27.

9 DM Chirwa 'The doctrine of state responsibility as a potential means of holding private actors accountable for human rights' (2004) 5 Melbourne Journal of International Law 2.

10 M Moore 'Obstacles to increasing tax revenues in low-income countries' http:// papers.ssrn.com/sol3/papers.cfm?abstract_id=2436437 (accessed 28 November 2018). 
middle-income countries are disadvantaged by international rules, as a significant proportion of global wealth is held offshore (that is, in secrecy and in low tax jurisdictions) and is untaxed. ${ }^{11}$ The amount of income tax paid by corporations is influenced by the practices of multinational enterprises (MNEs) working in the country, but tax policies are also guided by the International Monetary Fund (IMF) and thus high-income countries. These entities encourage a reduction in corporate and personal income tax, international trade tax and a replacement with value-added taxes, often considered to be regressive. ${ }^{12}$ When a country is impoverished or indebted, the volume of aid and credit is significant and decided mainly by high-income countries, the World Bank and the IMF. ${ }^{13}$

An examination of leakages of revenue from low and middleincome countries' governments shows that the most significant are tax avoidance in the informal sector, tax incentives granted to the corporate sector and international corporate tax avoidance ${ }_{15}^{14}$ while other leakages include corruption and debt repayments. ${ }^{15}$ These leakages may be increased or decreased by the policies and practices of MNEs, high-income countries and international organisations, the IMF and the World Bank.

Current frameworks to assess compliance with the obligation to fulfil economic, social and cultural rights are cognisant of the responsibilities of a state for the realisation of these rights. ${ }^{16}$ However, there is a need for an extended framework to include global actors. Given this gap, we developed a framework to facilitate the systematic audit of the policies and practices of the main global actors that may affect leakages of revenue and thus public services and survival rights in low and middle-income countries, see figure 2. This is similar to other frameworks developed to analyse the impact of globalisation, but viewed through the lens of human rights, which are also among the Sustainable Development Goals (SDGs). ${ }^{17}$ It is an upstream extension of the OPERA framework (outcomes, policy effort, resources

11 M Moore, W Prichard \& O-H Fjeldstad Taxing Africa: Coercion, reform and development (2018).

12 C Kumar 'Africa rising?' (2014) https://www.christianaid.org.uk/sites/default/files/ 2017-08/africa-rising-inequalities-essential-role-fair-taxation-february-2014.pdf (accessed 28 November 2018).

13 TH Stubbs, AE Kentikelenis \& LP King 'Catalyzing aid? The IMF and donor behaviour in aid allocation' (2016) 78 World Development 511.

14 M Curtis \& B O'Hare 'Lost revenues in low income countries' (2017) 3 http:// curtisresearch.org/publications/lost-revenues-in-low-income-countries/ (accessed 28 November 2018).

15 B O'Hare \& I Makuta 'An analysis of the potential for achieving the fourth millennium development goal in SSA with domestic resources' (2015) 11 Global Health 8.

16 Ashford (n 6).

17 R Labonte \& R Torgerson 'Interrogating globalisation, health and development: Towards a comprehensive framework for research, policy and political action' (2005) 15 Critical Public Health 157. 
and assessment), as the influence of global actors on (a) the policies and (b) revenues available (generation and allocation) is included. ${ }^{18}$

In terms of measuring the outcomes with respect to survival rights, socio-economic data is collected by many organisations and is widely available and well-suited to analysing levels of rights, provided the data is reported as the percentage of the population (and, therefore, children) who do not have access to water, sanitation, health care and primary education. ${ }^{19}$ For example, if 70 per cent of children have access to improved water, then 30 per cent of children do not have access to this right.

\section{Results: A four-step audit of upstream influences on the survival rights of children in low and middle- income countries}

The following four steps may be used to systematically analyse the influences of the national government and global actors on policy effort and revenue, in terms of both generation and allocation, which impact the realisation of survival rights, see table 1 for the upstream influences on revenue. This article highlights some aspects to consider in each of the steps, but the analysis need not be limited to these suggestions.

\subsection{Step I: National}

\subsubsection{Policy effort}

Has the country ratified the international covenants and treaties? Are survival rights in the constitution and national legislation? Is there an implementation strategy and guidelines? Are socio-economic rights justiciable and is justice accessible in the national human rights system? What are the outcomes of litigation on survival rights or minimum core economic and social rights?

\subsubsection{Resource generation}

The audit of resources should include how effectively a country raises revenue, including tax, as this will influence the ability to meet their human rights obligations. ${ }^{20}$ Has the country designed their tax regimes to facilitate human rights obligations, for instance, by

18 Centre for Economic and Social Rights The OPERA framework: Assessing compliance with the obligation to fulfil economic, social and cultural rights (2012) 1 http:// cesr.org/opera-landing (accessed 18 November 2018).

19 Office of the United Nations High Commissioner for Human Rights Human rights indicators: A guide to measurement and implementation (2012) http://www. ohchr.org/Documents/Publications/Human_rights_indicators_en.pdf (accessed 28 November 2018); O'Hare, Devakumar \& Allen (n 4).

20 R Balakrishnan, D Elson \& R Patel 'Rethinking macro-economic strategies from a human rights perspective' (2010) 53 Development 27-36 
redistributing wealth to mitigate social inequalities and to generate a revenue stream for social goods? ${ }^{21}$

Government revenue is lower in low and middle-income countries than in high-income countries (18 per cent of gross domestic product (GDP) versus 42 per cent in high-income countries). ${ }^{22}$ The tax gap is the difference between revenue collected and what could be collected, and not taxing the informal sector contributes significantly to the gap. In many low and middle-income countries, the informal sector constitutes between 30 and 50 per cent of total productivity. ${ }^{23}$ If a country does not demonstrate due diligence in raising taxes and is unable to provide survival rights due to a shortage of revenue, then human rights obligations are not being met. However, raising taxes in low and middle-income countries is challenging for logistic and political reasons. Low and middle-income countries generally are agricultural and use physical verification rather than account-based taxing and tax administrations tend to be underresourced regarding staff and funding. ${ }^{24}$ Also, there may be a lack of political will to tax the wealthy elite due to vested interests. ${ }^{25}$ Tax incentives are commonly used to attract direct foreign investment, but investors also need a good infrastructure and regulatory environment, which cannot be provided without government revenue. ${ }^{26}$ The IMF and World Bank note that tax incentives create an administrative burden for tax authorities and do not promote investment, yet more than half the African countries offer generous incentives. For example, in 2007 it was estimated that Mozambique lost 77 per cent of corporate income tax due to incentives. ${ }^{27}$ While there is parliamentary scrutiny of general budgets, tax policies may not receive the same degree of oversight. $^{28}$ Donor agencies themselves are often beneficiaries of tax exemptions, which increases the transaction costs of aid and increases

21 D Mccoy, S Chigudu \& T Tillmann 'Framing the tax and health nexus?: A neglected aspect of public health concern' (2017) 12 Health Economics, Policy and Law 179.

22 Moore (n 10).

23 L Medina, A Jonelis \& M Cangul 'The informal economy in sub-Saharan Africa?: Size and determinants' (2017) http://www.imf.org/en/Publications/WP/Issues/ 2017/07/10/The-Informal-Economy-in-Sub-Saharan-Africa-Size-and-Determinants45017?cid=em-COM-123-35579 (accessed 18 November 2018).

24 Moore (n 10).

25 A Waris 'How Kenya has implemented and adjusted to the changes in international transfer pricing regulations, 1920-2016' International Centre for Tax and Development Working Paper 69 (2017).

26 OECD Action plan on base erosion and profit shifting (2013)

27 Action Aid 'Give us a break: How big companies are getting tax-free deals' June 2013, http://www.actionaid.org/sites/files/actionaid/give_us_a_break_-_how_big_ companies_are_getting_tax-free_deals_2.pdf (accessed 18 November 2018).

28 M Hearson 'Tax-motivated illicit financial flows: A guide for development practitioners' (2014) http://www.u4.no/publications/tax-motivated-illicit-financialflows-a-guide-for-development-practitioners/ (accessed 18 November 2018). 
tax fraud. ${ }^{29}$ Import taxes are a vital source of government revenue for low and middle-income countries, but these have decreased as a result of liberalisation policies, ${ }^{30}$ and aid. ${ }^{31}$

The High-Level Panel on illicit financial flows from Africa has defined flows as

money that is illegally earned, transferred or utilised. These funds typically originate from three sources: commercial tax evasion, trade misinvoicing and abusive transfer pricing; criminal activities, including the drug trade, human trafficking, illegal arms dealing, and smuggling of contraband; and bribery and theft by corrupt government officials. ${ }^{32}$

Most instances of illicit financial flight are to avoid taxes, generally commercial tax abuse. Corporate income tax is due when profit is declared, and overestimating costs and underestimating profit may be used for transactions between related entities (called transfer pricing) to artificially lower profits and thus taxes. Sales between related entities are supposed to use an 'arm's length' approach to pricing, but this is rarely used. Profits are thus shifted from jurisdictions with higher levels of taxation to low tax jurisdictions, which may also have high levels of secrecy. Tax treaties between high-income countries and low and middle-income countries are used, and companies are established in a country where there is a tax treaty in place in order to divert profits and minimise tax. High-income countries lose the most in absolute terms, but low and middle-income countries lose the most as a proportion of revenue. ${ }^{33}$ The impact is compounded by a heavy reliance on corporate income tax due to a large informal sector.

Due diligence is required with respect to raising revenue and includes taxing the informal sector and the wealthy. In terms of international corporate tax avoidance, tax treaties and incentives must be carefully and transparently considered prior to signature and all MNCs should be required to submit their global country-by-country reports of profits and taxes paid, to the revenue authorities of the low and middle-income countries where they operate. 29 V Thuronyi 'Committee of Experts on International Cooperation in Tax Matters' aspects-E-C18-2005-9.pdf (accessed 18 November 2018).

30 Moore (n 10).

31 W Prichard, JF Brun \& O Morrissey 'Donors, aid and taxation in developing countries: An overview' (2012) Report 6 http://www.ictd.ac/publication/donorsaid-and-taxation-in-developing-countries-an-overview/ (accessed 18 November 2018).

32 United Nations Economic Commission for Africa 'Report of the High-Level Panel on Illicit Financial Flows from Africa (2014).

33 A Cobham \& P Janský 'Global distribution of revenue loss from corporate tax avoidance?: Re-estimation and country results' (2018) 232 Journal of International Development 206. 


\subsubsection{Resource allocation and utilisation}

As well as legislating and raising revenue, governments are obliged to channel resources towards human rights, and these rights can only be sustainably funded with a fiscal process that is legitimate (transparent, accountable and participatory) and uses domestic revenues for public services in order to strengthen the state-citizen relationship, which, in turn, will generate ongoing tax revenues. ${ }^{34}$ Therefore a state's budget needs to be aligned with these ambitions. Resource allocation concerning survival rights should be assessed according to the proportion of the government's budget allocated to goods that will promote human development. Countries that have recently been involved in conflict tend to spend more on defence and less on health and education, which will compromise survival rights. ${ }^{35}$ Corruption, whether bureaucratic or political, decreases available resources for survival rights and has a negative impact on economic growth and, therefore, on tax generation. ${ }^{36}$ The allocation of government revenue through a corrupt system will result in public services of poor quality, which reduces tax morale and increases avoidance. ${ }^{37}$ Therefore public spending has little impact on outcomes in the presence of corruption, $^{38}$ and the school dropout rate is five times higher in corrupt countries. ${ }^{39}$ A more efficient government is more likely to meet their human rights obligations with scarce resources, for example, the same amount of health expenditure has a greater impact on health outcomes where there is good governance. ${ }^{40}$ An inefficient administration and procurement practice, overpricing and absenteeism hinder the implementation of well-intended social policies. 41

34 A Waris \& LA Latif 'Towards establishing fiscal legitimacy through settled fiscal principles in global health financing' (2015) 23 Health Care Analysis 376.

35 B O'Hare \& DP Southall 'First do no harm: The impact of recent armed conflict on maternal and child health in sub-Saharan Africa' (2007) 100 Journal of the Royal Society of Medicine 564.

36 M Ugur \& N Dasgupta 'Systematic review: Evidence on the economic growth impacts of corruption in low-income countries and beyond' (2011) http:// r4d.dfid.gov.uk/PDF/Outputs/SystematicReviews/Corruption_impact_2011_Ugur report.pdf (accessed 18 November 2018).

37 S Gupta, M Verhoeven \& ER Tiongson 'The effectiveness of government spending on education and health care in developing and transition economies' (2002) 18 European Journal of Political Economy 717.

38 I Makuta \& B O'Hare 'Quality of governance, public spending on health and health status in sub-Saharan Africa: A panel data regression analysis' (2015) 15 BMC Public Health 932.

39 Gupta, Verhoeven Tiongson (n 37).

40 E Willebois, EM Halter, R Harrison et al 'The puppet masters: How the corrupt use legal structures to hide stolen assets and what to do about it' (2011) $267 \mathrm{https://}$ star.worldbank.org/star/sites/star/files/puppetmastersv1.pdf (accessed 18 November 2018).

41 The World Bank 'Silent and lethal: How quiet corruption undermines Africa's development efforts' (2010) http://documents.worldbank.org/curated/en/3160 $51468009960660 /$ Silent-and-lethal-how-quiet-corruption-undermines-Africasdevelopment-efforts (accessed 18 November 2018). 


\subsection{Step II: Multinational enterprises}

\subsubsection{Influence on policy effort}

Multinational enterprises may positively influence policy space with good corporate responsibility towards the country and communities where they work or negatively by using bribery or political lobbying to change policies in their interest. ${ }^{42} \mathrm{MNEs}$ also have huge latent power due to their ability to relocate investment elsewhere. ${ }^{43}$

\subsubsection{Influence on resource generation}

MNEs positively and significantly add to government revenue through job creation and taxes. Corporate tax is especially crucial in low and middle-income countries as the ratio of corporate income tax to other taxes is much higher than in high-income countries. ${ }^{44}$ However, MNEs may seek to avoid tax by eroding their tax base by shifting profits to low tax jurisdictions or by seeking tax incentives. Favourable terms are more likely when there is a lack of transparency. Tax avoided by MNEs in low and middle-income countries ends up in high-income countries and in offshore financial centres, and the enabling role of accountants, lawyers and bankers is increasingly recognised. ${ }^{45}$

\subsection{Step III: High-income countries including development partners}

\subsubsection{Influence on policy effort}

The role of donors in allocation decisions needs to be carefully considered, especially where most of the government budget is derived from aid. It is crucial that survival rights be prioritised by donors where there is not complete coverage. For example, despite the importance of maternal education to child health, 46 aid allocated to education is stagnating. ${ }^{47}$ The non-aid policies of high-income countries, may indirectly, either positively or negatively, impact survival rights in low and middle-income countries. For example, policies that protect the environment and support the transfer of new technology and fair trade will promote survival rights. Negative

\footnotetext{
42 Willebois, Halter \& Harrison (n 40) 267.

43 Chirwa (n 9).

44 Moore (n 10).

45 International Bar Association 'Tax abuses, poverty and human rights' (2013) http:/ /www.ibanet.org/Human_Rights_Institute/TaskForce_IllicitFinancialFlows_Poverty_ HumanRights.aspx (accessed 18 November 2018).

46 E Gakidou, K Cowling, R Lozano et al 'Increased educational attainment and its effect on child mortality in 175 countries between 1970 and 2009: A systematic analysis' (2010) 376 The Lancet 959.

47 UNESCO 'Aid to education is stagnating and not going to countries most in need' (2017) http://unesdoc.unesco.org/images/0024/002495/249568e.pdf (accessed 18 November 2018).
} 
interventions, such as economic sanctions, military interventions and financial secrecy adversely impacts survival rights. ${ }^{48}$ Countries that initiate or vote for actions on international bodies bear responsibility if human rights are violated.

\subsubsection{Influence on resource generation}

Aid used for human development, infrastructure and supporting tax administrations may increase survival rights. However, aid-funded goods and services are exempt from taxation, and this situation burdens under-resourced tax administration which compromises the core objective of establishing a sustainable tax base. ${ }^{49}$ Donor conditions may include tied procurement which may be more expensive and result in an extra level of bureaucracy.

Tax avoidance by MNEs, often headquartered in high-income countries which may also be development partners, decreases the government revenue available for survival rights. Countries that provide financial secrecy are facilitating tax abuses and thus human rights abuses. ${ }^{50}$ Tax treaties between high-income countries and low and middle-income countries often limit the latter's ability to tax MNEs and allows 'treaty shopping', which occurs when a subsidiary is opened in a country which offers the most favourable treaty in order to divert profits. ${ }^{51}$ Repayment of debt can reduce the resources available for survival rights, ${ }^{52}$ for example, 50 per cent of capital loaned to African countries as public debt (which has to be repaid), was deposited in private bank accounts in high-income countries within months of the loan being granted. Debts that did not benefit the population, about which they had no knowledge and in situations where the creditors were aware of the circumstances, are defined as odious in international law. ${ }^{53}$ These debts need to be audited and repudiated, and the role of high-income countries in which the lending institutions are domiciled need to consider their obligations when granting loans. Obstacles to trade in agricultural products are significant and include subsidies granted to farmers in high-income countries which lowers world prices, and other barriers such as import tariffs, quotas and stringent phyto-sanitary conditions. High-income

48 Centre for Global Development, 'Commitment to Development Index', 2015 http://www.cgdev.org/cdi-2015 (accessed 18 November 2018)

49 Prichard, Brun \& Morrissey (n 31).

50 Cobham, Alex, Petr Janský, and Markus Meinzer, 'The Financial Secrecy Index? Shedding New Light on the Geography of Secrecy Working Paper 404', 2015 https://www.cgdev.org/publication/financial-secrecy-index-shedding-new-lightgeography-secrecy-working-paper-404 (accessed 18 November 2018)

51 ActionAid 'Mistreated The tax treaties that are depriving the world's poorest countries of vital revenue' (2016) http://www.actionaid.org/sites/files/actionaid/ actionaid_-_mistreated_tax_treaties_report_-_feb_2016.pdf (accessed 18 November 2018).

52 O'Hare \& Makuta (n 14) 8.

53 L Ndikumana \& J Boyce Africas odious debts: How foreign loans and capital flight bled a continent (2011) 152. 
countries may promote the sale of arms to low and middle-income countries by protecting the profit of arms traders through offering a guarantee for their investment. ${ }^{54}$

\subsection{Step IV: International organisations}

\subsubsection{Influence on policy effort}

The IMF is the gatekeeper for World Bank credit ${ }^{55}$ and aid flows, 56 and is an important player in global development. 57 The IMF will impact survival rights when privatisation is promoted or if a restriction on social spending prohibits a country's ability to provide for all. ${ }^{58}$ The World Bank decides about credit allocation and to whom lowinterest loans are awarded. The scale of their portfolio makes oversight difficult, and criticisms include their corrupting influence, with 10 to 40 per cent of loans and grants lost due to a lack of fiduciary oversight, ${ }^{59}$ corruption impacts the efficiency with which a government provides survival rights. ${ }^{60}$ Voting power at the IMF and World Bank is skewed towards high-income countries (see Table 2). The failure of countries to meet their obligations to provide survival rights, as a result of the policies of international organisations is the responsibility of the countries that have delegated powers to them.

\subsubsection{Influence on resource generation}

Adjustment and poverty reduction loans often come with the conditionality of reducing import taxes and opening markets to foreign trade and investment. The reduction in import taxes has resulted in the loss of government revenue, and most low and middleincome countries have managed to replace only 30 per cent of this, as their economies predominantly are informal economies with a narrow tax base. ${ }^{61}$ Conditionalities need to be viewed through the lens of human rights. This requirement may compromise new industries which may not be competitive in a global marketplace, although, for importing countries, goods may be cheaper. The IMF has been involved in the reform of national tax agencies to optimise domestic resource mobilisation. However, without global tax reform

54 O'Hare \& Southall (n 35) 564.

55 CD Gowen 'IMF conditionality and armed civil conflict?: An analysis of subSaharan Africa' (2007) http://scholarworks.gsu.edu/political_science_theses/15/ (accessed 18 November 2018).

56 B Clements, S Gupta \& M Nozaki 'What happens to social spending in IMFsupported programmes?' (2013) 48 Applied Economics 4022.

57 Stubbs, Kentikelenis \& King (n 13) 511.

58 AE Kentikelenis 'Structural adjustment and health: A conceptual framework and evidence on pathways' (2016) 187 Social Science and Medicine 296.

59 S Berkman The World Bank and the gods of lending (2008).

60 Makuta \& O'Hare (n 38).

61 O Fjeldstad 'Taxation and development: A review of donor support to strengthen tax systems in developing countries' (2013) WIDER Working Paper 2013/010. 
the impact is likely to be negligible. ${ }^{62}$ If credit is in the form of a loan from the World Bank, then repayment may compromise the provision of survival rights. Loans may be worthwhile if used to support economic growth and human development, but credit which is not productive, will result in citizens repaying a debt from which they did not benefit.

\subsubsection{Resource allocation and utilisation}

The allocation of revenue towards survival rights may be influenced by a budgetary deficit, as debt often results in conditions including the privatisation of public goods such as health care or education, reduced social spending and caps on public sector salaries. The IMF has been associated with these policies, ${ }^{63}$ which generally reduces access to survival rights.

\section{Discussion}

The purpose of this audit is to identify modifiable barriers to children's right to survive which should increase the efficiency of child advocacy, as it allows targeting scarce advocacy resources towards the correct institutions. If violations are identified, it may be possible to remedy these through negotiation, for example, by requesting that international assistance prioritises changes in the policies of highincome countries, which have a spill-over impact on low and middleincome countries, that is, requesting development partners to have coherent policies. If tax avoidance plays a role, explaining to MNEs working in the country the importance of corporate tax to government revenue, public services and survival rights and negotiating for increased tax revenues as part of the corporation's social responsibility obligations, in preference to, or as well as sponsoring small projects for the local community. ${ }^{64}$

The decision regarding litigation to promote the realisation of core socio-economic rights will depend on several factors, including investigating whether the rights are recognised in the constitution; how easy it is to access courts in the country; the possibilities for public interest litigation; and how autonomous the judiciary is. A final question arises as to whether previous social rights litigation has improved access for the poor and vulnerable in the country. The

62 Moore (n 10).

63 AE Kentikelenis, TH Stubbs \& LP King 'Structural adjustment and public spending on health: Evidence from IMF programmes in low-income countries' (2015) 126 Social Science and Medicine 169.

64 Office of the United Nations High Commissioner for Human Rights. Guiding Principles on Business and Human Rights (2011), http://www.ohchr.org/Docu ments/Publications/GuidingPrinciplesBusinessHR_EN.pdf (accessed 18 November 2018). 
various factors need to be weighed and assessed in order to decide how to proceed. ${ }^{65}$

As far as international organisations are concerned, global institutional arrangements are decided by the governments of affluent countries, answerable to citizens in these countries, who therefore are duty bearers for the arrangements made in their name. ${ }^{66}$ Professional enablers, such as bankers and nominees of shell companies, are many steps closer regarding influence or duty, but we are all complicit, by our voting, banking, consuming and investing decisions if these contribute to institutions, policies and practices that produce structural injustices. ${ }^{67}$

\section{Conclusion}

Children's rights advocates have long awaited the resolution of structural injustices that deprive children of their right to survive. However, by not vocally advocating for immediate action on survival rights, we have colluded in the fallacy that technical solutions will solve problems caused by economic injustices. To close the gap between de jure and de facto children's rights to survival, associations or individuals can start to look upstream for fundamental causes and remedies of a legal or persuasive nature, country by country, and advocate immediate change.

65 AE Yamin \& S Gloppen (eds) Litigating health rights: Can courts bring more justice to health? (2011).

66 TWM Pogge 'World poverty and human rights' (2005) 19 Ethics and International Affairs 1.

67 IM Young 'Political responsibility and structural injustice' (2003) https:// www.bc.edu/content/dam/files/schools/cas_sites/sociology/pdf/PoliticalResponsi bility.pdf (accessed 18 November 2018). B O'Hare 'Active Global Citizenship: Ethical Living to Promote Human Rights' Health and Human Rights Journal, https:// www.hhrjournal.org/2018/11/active-global-citizenship-ethical-living-to-promotehuman-rights/. 
Box 1: Minimum core economic and social rights ${ }^{68}$

The minimum core obligations are of immediate effect and require states to -

- ensure the right of access to employment, especially for disadvantaged and marginalised individuals and groups, enabling them to live a life of dignity;

- ensure access to the minimum essential food which is nutritionally adequate and safe, to ensure freedom from hunger for everyone;

- ensure access to basic shelter, housing and sanitation, and an adequate supply of safe drinking water;

- $\quad$ provide essential drugs as defined under the World Health Organisation (WHO) Action Programme on Essential Drugs;

- $\quad$ ensure free and compulsory primary education to all;

- ensure access to a social security scheme that provides a minimum essential level of benefits that cover at least essential health care, basic shelter and housing, water and sanitation, foodstuffs, and the most basic forms of education. 
Figure 1: Coverage of minimum core economic, social and cultural rights; water, sanitation, primary school education, essential vaccination. ${ }^{69}$

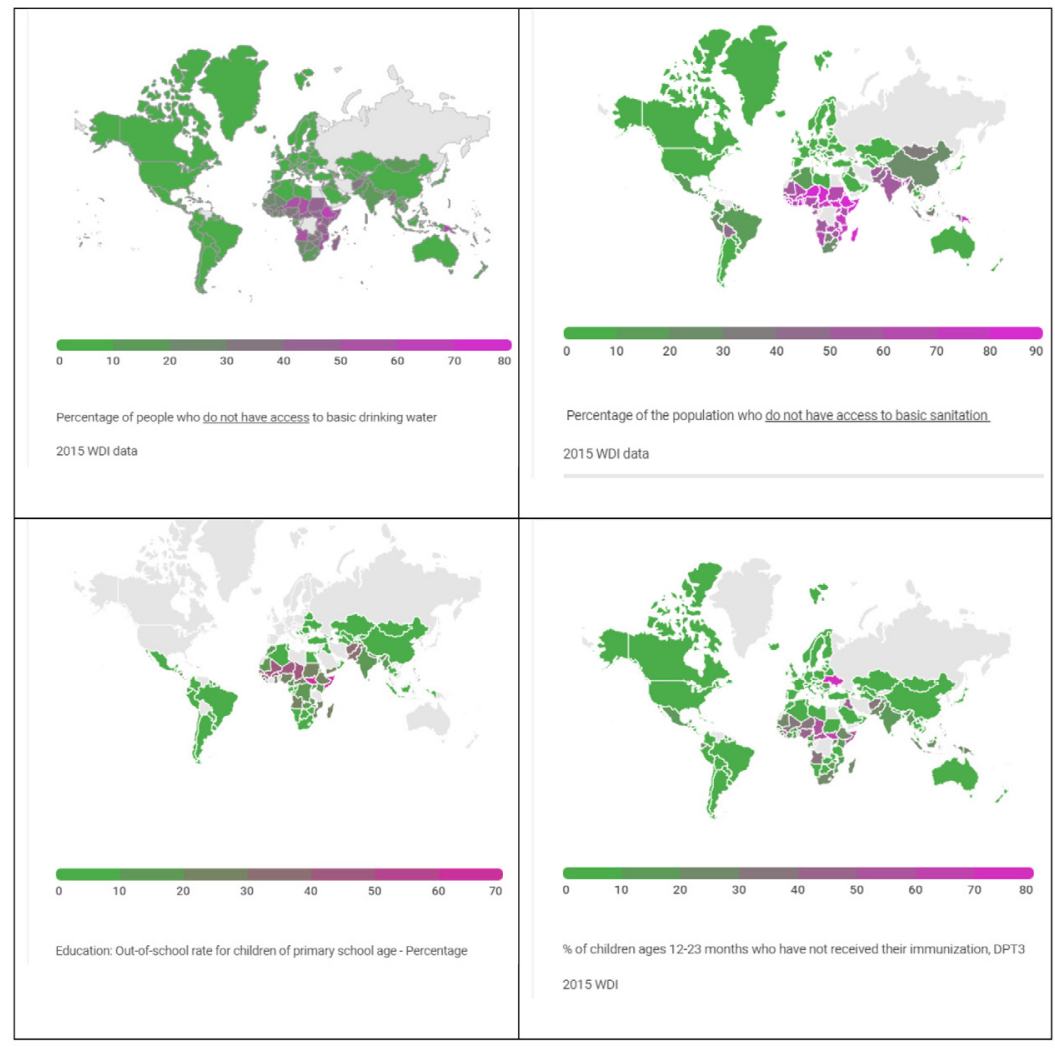

69 The World Bank. Databank - The World Bank. 2018. Available from: https:// data.worldbank.org/ (accessed 18 November 2018). 
Table 1: Upstream influences on government revenue (generation and allocation) in low and middle-income countries $(-)$ a barrier or likely adverse impact on access to survival rights $(+)$ facilitate or likely positive impact on access to survival rights

\begin{tabular}{|c|c|c|c|c|}
\hline & \begin{tabular}{|l} 
LMIC \\
governments
\end{tabular} & MNE & HIC & 10 \\
\hline $\begin{array}{l}\text { Tax } \\
\text { avoidance in } \\
\text { the informal } \\
\text { economy }\end{array}$ & $\begin{array}{l}\text { Tax } \\
\text { administra- } \\
\text { tions } \\
\text { underfunded } \\
\text { / staffed (-) } \\
\text { Well- } \\
\text { resourced tax } \\
\text { administra- } \\
\text { tions (+) }\end{array}$ & & $\begin{array}{l}\text { Aid used/not } \\
\text { used to } \\
\text { support tax } \\
\text { administratio } \\
\text { ns. (+/-) } \\
\text { Embassies } \\
\text { and aid } \\
\text { industry pay/ } \\
\text { do not pay } \\
\text { tax. (+/-) }\end{array}$ & $\begin{array}{l}\text { IMF technical } \\
\text { assistance for } \\
\text { tax } \\
\text { administratio } \\
\text { ns (+) } \\
\text { Global tax } \\
\text { rules (-) }\end{array}$ \\
\hline $\begin{array}{l}\text { Tax } \\
\text { incentives }\end{array}$ & $\begin{array}{l}\text { Transparency } \\
\text { /no } \\
\text { transparency } \\
\text { around } \\
\text { contracts. } \\
(+/-) \\
\text { Parliamentary } \\
\text { oversight/no } \\
\text { parliamentar } \\
\text { y oversight of } \\
\text { incentives } \\
\text { awarded. } \\
(+/-)\end{array}$ & $\begin{array}{l}\text { Aggressively } \\
\text { seek/do not } \\
\text { seek tax } \\
\text { incentives in } \\
\text { LMIC. } \\
(-/+)\end{array}$ & $\begin{array}{l}\text { HIC } \\
\text { government } \\
\text { do not } \\
\text { lobby/do } \\
\text { lobby LMIC } \\
\text { to grant their } \\
\text { MNE tax } \\
\text { incentives. } \\
\text { (+/-) }\end{array}$ & $\begin{array}{l}\text { Encourage } \\
\text { incentives to } \\
\text { attract } \\
\text { foreign direct } \\
\text { investment } \\
\text { by MNEs } \\
\text { which do/do } \\
\text { not avoid } \\
\text { tax. }(-/+)\end{array}$ \\
\hline $\begin{array}{l}\text { International } \\
\text { corporate tax } \\
\text { avoidance }\end{array}$ & $\begin{array}{l}\text { Legislation/ } \\
\text { no legislation } \\
\text { for country- } \\
\text { by-country } \\
\text { reporting by } \\
\text { all MNE } \\
\text { doing } \\
\text { business in } \\
\text { the } \\
\text { country.(+/-) } \\
\text { Not a } \\
\text { signatory/ } \\
\text { signatory to } \\
\text { treaties } \\
\text { which } \\
\text { reduces tax } \\
\text { sovereignty. } \\
\text { (+/-) }\end{array}$ & $\begin{array}{l}\text { The use of } \\
\text { tax planning } \\
\text { to lower tax } \\
\text { due in LMIC. } \\
(-) \\
\text { Subsidiaries } \\
\text { in } \\
\text { jurisdictions } \\
\text { with low tax } \\
\text { rates. (-) } \\
\text { No use of tax } \\
\text { avoidance by } \\
\text { MNE. (+) } \\
\text { Country-by- } \\
\text { country } \\
\text { reporting of } \\
\text { profits and } \\
\text { tax paid. (+) }\end{array}$ & $\begin{array}{l}\text { Public } \\
\text { country-by- } \\
\text { country } \\
\text { reporting by } \\
\text { MNE/no } \\
\text { reporting by } \\
\text { MNE. (+/-) } \\
\text { Regulate/ do } \\
\text { not regulate } \\
\text { domiciled } \\
\text { MNE which } \\
\text { avoid tax in } \\
\text { LMIC, (even } \\
\text { those which } \\
\text { are } \\
\text { development } \\
\text { partners). } \\
\text { (+/-) } \\
\text { No tax } \\
\text { treaties/tax } \\
\text { treaties } \\
\text { which limit } \\
\text { LMIC taxing } \\
\text { ability. (+/-) }\end{array}$ & $\begin{array}{l}\text { Contracts to } \\
\text { MNE which } \\
\text { avoid tax. (-) } \\
\text { Due diligence } \\
\text { regarding } \\
\text { awarding } \\
\text { contracts to } \\
\text { MNE re tax. } \\
(+)\end{array}$ \\
\hline
\end{tabular}




\begin{tabular}{|c|c|c|c|c|}
\hline Corruption & $\begin{array}{l}\text { Strong/weak } \\
\text { anti- } \\
\text { corruption } \\
\text { policies.(+/-) }\end{array}$ & $\begin{array}{l}\text { Use/avoid } \\
\text { bribery to } \\
\text { obtain } \\
\text { incentives or } \\
\text { contracts. } \\
(+/-)\end{array}$ & \begin{tabular}{|l} 
Do not \\
enforce anti- \\
money \\
laundering \\
policies or \\
support \\
stolen asset \\
recovery. (-) \\
No public \\
beneficial \\
ownership \\
legislation.(-) \\
Support \\
financial \\
secrecy. (-)
\end{tabular} & $\begin{array}{l}\text { Little } \\
\text { oversight/ } \\
\text { oversight of } \\
\text { loans and } \\
\text { grants. }(-/+)\end{array}$ \\
\hline $\begin{array}{l}\text { Debt } \\
\text { repayment }\end{array}$ & $\begin{array}{l}\text { Carry out/do } \\
\text { not carry out } \\
\text { debt } \\
\text { audits.(+/-) } \\
\text { Public aware/ } \\
\text { unaware of } \\
\text { credit and } \\
\text { purpose. } \\
(+/-)\end{array}$ & & $\begin{array}{l}\text { Support/do } \\
\text { not support } \\
\text { debt audits } \\
\text { and asset } \\
\text { recovery. } \\
(+/-)\end{array}$ & $\begin{array}{l}\text { Loans. (-) } \\
\text { Grants with } \\
\text { fiduciary } \\
\text { oversight (+) }\end{array}$ \\
\hline $\begin{array}{l}\text { Import tax } \\
\text { barriers to } \\
\text { exports or } \\
\text { prices with } \\
\text { subsidies }\end{array}$ & & & $\begin{array}{l}\text { Promote } \\
\text { liberalisation } \\
\text { policies. (-) } \\
\text { Protect HIC } \\
\text { industries } \\
\text { and subsidise } \\
\text { agriculture. } \\
(-)\end{array}$ & $\begin{array}{l}\text { Liberalisation } \\
\text { policies } \\
\text { which } \vee \text { tax } \\
\text { on imports } \\
\text { and increase } \\
\text { competition } \\
\text { for local } \\
\text { business. (-) }\end{array}$ \\
\hline Allocation & $\begin{array}{l}\text { Minimal/ } \\
\text { excessive } \\
\text { defence } \\
\text { spending. } \\
(+/-) \\
\text { No debt/ } \\
\text { large debt } \\
\text { repayment. } \\
(+/-)\end{array}$ & $\begin{array}{l}\text { Promote } \\
\text { militarisation. } \\
(-) \\
\text { Do not } \\
\text { promote } \\
\text { defence } \\
\text { spending in } \\
\text { countries } \\
\text { with low } \\
\text { survival rights } \\
\text { coverage. }(+)\end{array}$ & $\begin{array}{l}\text { Aid allocation } \\
\text { which does } \\
\text { not prioritise } \\
\text { survival } \\
\text { rights. (-) } \\
\text { Untied/tied } \\
\text { aid. (+/-) } \\
\text { Promote } \\
\text { militarisation, } \\
\text { license arms } \\
\text { transfers and } \\
\text { provide } \\
\text { credit } \\
\text { guarantees } \\
\text { for arms } \\
\text { exports to } \\
\text { LMIC. (-) }\end{array}$ & $\begin{array}{l}\text { The } \\
\text { privatisation } \\
\text { of providers } \\
\text { of survival } \\
\text { rights. (-) } \\
\text { Promote } \\
\text { restriction on } \\
\text { social } \\
\text { spending. (-) }\end{array}$ \\
\hline
\end{tabular}


Figure 2: Conceptual framework to analyse the upstream obstacles to survival rights. Step 1-IV of the four step audit of national and global barriers

\begin{tabular}{|c|}
\hline $\begin{array}{l}\text { II MNE } \\
\text { Tax avoidance } \\
\text { Tax incentives }\end{array}$ \\
\hline $\begin{array}{l}\text { I National } \\
\text { government } \\
\text { Lost } \\
\text { revenues } \\
\text { Failure to tax } \\
\text { the informal } \\
\text { sector } \\
\text { Granting Tax } \\
\text { exemptions - } \\
\text { Corruption, } \\
\text { debt and } \\
\text { allocation } \\
\text { decisions }\end{array}$ \\
\hline
\end{tabular}
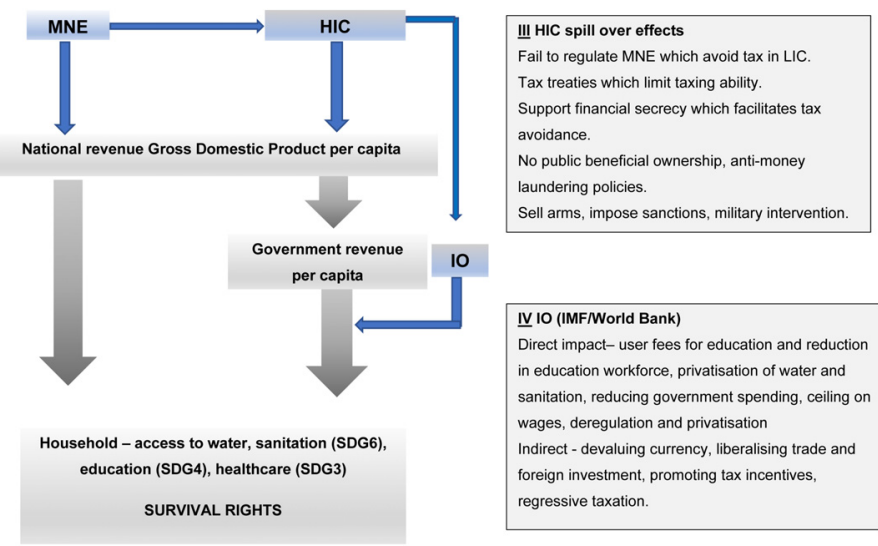
Table 2: Voting power as a percentage of total at international financial organisations. ${ }^{70}$

\begin{tabular}{|l|l|l|l|}
\hline & IMF & $\begin{array}{l}\text { International Bank } \\
\text { for Reconstruction } \\
\text { and Development } \\
\text { (IBRD) }\end{array}$ & $\begin{array}{l}\text { International Finance } \\
\text { Corporation } \\
\text { (IFC) }\end{array}$ \\
\hline USA & 16.52 & 15.98 & 20.99 \\
\hline Japan & 6.15 & 6.89 & 6.01 \\
\hline China & 6.09 & 4.45 & 2.30 \\
\hline Germany & 5.32 & 4.03 & 4.77 \\
\hline France & 4.03 & 3.78 & 4.48 \\
\hline UK & 4.03 & 3.78 & 4.48 \\
\hline Italy & 3.02 & 2.66 & 3.02 \\
\hline Russia & 2.59 & 2.82 & 3.82 \\
\hline Canada & 2.22 & 2.45 & 3.02 \\
\hline Saudi Arabia & 2.02 & 2.79 & 1.91 \\
\hline SUBTOTAL & 51.99 & 49.63 & 54.8 \\
\hline Rest of World & 48.01 & 50.37 & 45.2 \\
\hline
\end{tabular}

70 The World Bank. International bank for Reconstruction and Development (IBRD): SUBSCRIPTIONS AND VOTING POWER OF MEMBER COUNTRIES. 2018, http:// pubdocs.worldbank.org/en/795101541106471736/IBRDCountryVotingTable.pdf (accessed 18 November 2018).

The World Bank. International Finance Corporation (IFC): SUBSCRIPTIONS AND VOTING POWER OF MEMBER COUNTRIES. 2018, http://pub docs.worldbank.org/ en/280961541106482420/IFCCountryVotingTable.pdf (accessed 18 November 2018). 